The Dickson Poon School of Law

SomersetHouse EastWing

Strand, London, WC2R 2LS

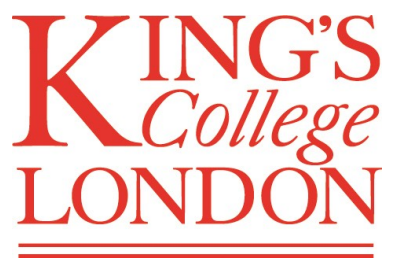

\title{
Precarious Finality? Reflections on res judicata and the Question of the Delimitation of the Continental Shelf case
}

\section{Niccolò Ridi}

King's College London Dickson Poon School of Law Legal Studies Research Paper Series: Paper No. 2018-02 


\title{
Precarious Finality? Reflections on res judicata and the Question of the Delimitation of the Continental Shelf case
}

\author{
Niccolò Ridi*
}

\section{Introduction}

On 17 March 2016 the International Court of Justice (ICJ) delivered its judgment on preliminary objections raised by Colombia in the case concerning the Question of the Delimitation of the Continental Shelf between Nicaragua and Colombia beyond 200 nautical miles from the Nicaraguan Coast. ${ }^{1}$ The rejection of the respondent's third preliminary objection, contending that the principle of res judicata barred a re-examination of Nicaragua's application, was only reached through the casting vote of the President, as the Court found itself evenly split on the matter. Specifically, the question was whether the application should have been declared inadmissible on the grounds that the issues raised in the case had been decided in the 2012 decision in Territorial and Maritime Dispute (Nicaragua v. Colombia), between the same parties. ${ }^{2}$

The 2016 judgment thus joins the small number of ICJ judgments in which the Court was evenly split, which had not occurred since the Nuclear Weapons Advisory Opinion. ${ }^{3}$ Intriguingly, such a fracture seems to have been prompted by differences between the

\footnotetext{
* LLB/MA (University of Florence); LLM (Cantab); PhD Candidate (Modern Law Review Scholar), The Dickson Poon School of Law, King's College London; Collaborateur de recherche, Graduate Institute of International and Development Studies, Geneva. niccolo.ridi@kcl.ac.uk; niccolo.ridi@graduateinstitute.ch. I am grateful to Philippa Webb, John Tasioulas, Peer Zumbansen, Esmé Shirlow, Luíza Leão Soares Pereira, Napoleon Xanthoulis, and anonymous reviewers for their invaluable comments. All errors remain my own.

${ }^{1}$ Question of the Delimitation of the Continental Shelf between Nicaragua and Colombia beyond 200 nautical miles from the Nicaraguan Coast (Nicaragua v. Colombia), Preliminary Objections, Judgment of 17 March 2017 (not yet published) (hereinafter: Delimitation of the Continental Shelf). On the same day, the Court also delivered its judgment in another case brought by the same applicant against the same respondent, Alleged Violations of Sovereign Rights and Maritime Spaces in the Caribbean Sea (Nicaragua v. Colombia), Preliminary Objections, Judgment of 17 March 2017 (not yet published).

${ }^{2}$ Territorial and Maritime Dispute (Nicaragua v. Colombia), Judgment of 19 November [2012] ICJ Rep. 624 (hereinafter Territorial and Maritime Dispute).

${ }^{3}$ Legality of the Threat or Use of Nuclear Weapons, Advisory Opinion, 8 July 1996, [1996] ICJ Rep. 226. The Court was also evenly split were the controversial South West Africa (Ethiopia v. South Africa), Second Phase, Judgment of 18 July 1966, [1966] ICJ Rep. 6, and so was the Permanent Court of International Justice in the SS Lotus case (France v. Turkey), PCIJ Rep Series A No. 10. More recently, the Court found itself split in Obligations concerning Negotiations relating to Cessation of the Nuclear Arms Race and to Nuclear Disarmament (Marshall Islands v. United Kingdom), Preliminary Objections, Judgment of 5 October 2016 (not yet published).
} 
judgments over the operation of a procedural principle, the understanding of which is comparatively uncontroversial. Upon closer analysis, however, the contrast between the majority and the minority, with several members issuing a vocal joint dissent and individual declarations, reveals that more divisive questions relating to the value of finality and the judicial function writ large were at stake.

The significance of these issues and the broader implications of the approach taken by the Court in its decision warrant further analysis. This article will proceed in three parts: first, it will provide an overview of the nature and purpose of the principle of res judicata, its application in international adjudication, and its use by the ICJ; second, it will analyse the Court's reading of the principle in the case at issue; third, it will assess the broader implications of one such approach for the role and authority of the International Court and the international judiciary.

\section{The principle of res judicata and international adjudication}

\subsection{Overview of res judicata and its rationales}

Res judicata, literally 'a matter that has already been judged', is principle that protects the finality of judgments. ${ }^{4}$ A shared feature of both civil and common law systems, it serves multiple purposes: as a matter of private justice, it protects defendants from having to be proceeded against multiple times for the same matter (nemo debet bis vexari pro una et eadem causa), and can thus be analogised with the cognate principle of ne bis in idem. ${ }^{5}$ As a matter of public policy, it ensures that there be an end to litigation (expedit rei publicae ut sit finis litium), furthers legal security considerations by preventing divergent decisions being taken on the same matter, and encourages the economic efficiency of the courts in both the second proceedings (by allowing the dismissal of the suit) and in the first (by charging the claimant with the burden of presenting a complete claim, rather than fragmenting it). ${ }^{6}$

Conceptually, res judicata is a relatively broad notion, covering a number of different effects of a final judgment, which may be classified as conclusive (meaning that the judgment is final and binding upon the parties) and preclusive (meaning that the matter cannot be subject

\footnotetext{
${ }^{4}$ The use of the Latin expression is widespread in English and German speaking countries, but literal translations are more commonly used elsewhere: for example, cosa juzgada, chose jugée, or cosa giudicata in Spanish, French, and Italian respectively.

${ }^{5}$ Y. Sinai, 'Reconsidering Res Judicata: A Comparative Perspective' (2010) DJCIL, at 353.

${ }^{6}$ R. A. Posner, 'An Economic Approach to Legal Procedure and Judicial Administration' (1973) JLS 399, 444.
} 
to further litigation). The first element depends on the formal finality of the judgment, which is subject to its own rules. The second element, in turn, derives from the first, and makes it impossible to re-open a matter that has been decided with a final judgment that is binding upon the parties. In this context, the effects of res judicata can be classified as procedural and substantive, the former serving as a procedural bar against a re-hearing of the dispute by the same court, the latter being broader in scope and designed to make the judgment govern the relationship between its parties with respect to the question it decided. ${ }^{7}$

Preclusive effects can be further categorised as causing either claim preclusion (or claim estoppel, by reference to the corresponding plea) or issue preclusion (issue or 'collateral' estoppel). ${ }^{8}$ Claim preclusion concerns the cause of action, whereas issue preclusion relates to issues of fact or law determined in the previous proceedings. Beyond terminological divergences in the literature, in most civil law systems and in international law issue preclusion questions are understood to lie beyond the theoretical boundaries of res judicata proper, with the consequence that the expression is usually given — and is given here — a narrower meaning. ${ }^{9}$ In this understanding, with some approximation, res judicata proper requires the satisfaction of a strict 'triple identity test', meaning that the parties, cause of action, and object of the claim must be the same.

\subsection{Res judicata in international adjudication: status, problems, and significance}

The applicability of res judicata in public international law litigation is today relatively uncontroversial, albeit the same cannot always be said of its actual application. ${ }^{10}$ For over a century, it has been employed and referred to with some frequency and confidence as an established rule of law. ${ }^{11}$ Following the well-known dissenting opinion of Judge Anzilotti in

\footnotetext{
${ }^{7}$ The two concepts may be more or less neatly distinguished in domestic law: by way of example, Article 324 of the Italian Code of Civil Procedure describes the essential elements of a final judgment (formal res judicata), whereas Article 2909 of the Civil Code illustrates the effects of the former (substantive res judicata). On the matter see, inter alia, M. Cappelletti, Civil Procedure in Italy (2013), 251.

${ }^{8}$ The first distinction is more common in the United States, whereas the second is typical of England and Canada. See Sinai, supra note 6, at 357.

${ }^{9}$ See also the interim report of the International Law Association Committee on International Commercial Arbitration: “"Res judicata” and Arbitration' (Berlin 2004) at 14.

${ }^{10}$ On res judicata in public international law in general, see E. Grisel, 'Res judicata: l'autorité de la chose jugée en droit international', in B. Dutoit, E. Grisel (eds) Mélanges Georges Perrin, 1984, 139; L.N.C. Brant, L'autorité de la chose jugée en droit international public (2003).

${ }^{11}$ The Pious Fund Case (United States of America v. Mexico) Vol IX UNRIAA 1, at 12 (1902); In the Matter of the SS Newchwang (Great Britain v. United States), Vol VI UNRIAA 64, at 65 (1921); Trail Smelter case (United States, Canada) Vol III UNRIAA 1905, at 1950 (1941): 'That the sanctity of res judicata attaches to a final decision of an international tribunal is an essential and settled rule of international law'.
} 
the Chorzów Factory case, res judicata has been usually qualified as a general principle of law in the sense of Article 38(1)(c) of the Court's Statute. ${ }^{12}$ As to the requirements of res judicata, the principle has been generally understood not to operate across legal orders, with the implication that only decisions by international tribunals (including mixed arbitration tribunals) may bar a subsequent claim. ${ }^{13}$ In practice, tribunals have set more exacting conditions, and have been reluctant to make a finding of res judicata in relation to a decision that they had not themselves issued, or which at least did not originate within the same system.

Continuing with the the oft-cited exposition by Anzilotti, a strict test must be carried out to ensure the cumulative identity of parties, object, and cause of action (persona, petitum, and causa petendi). ${ }^{14}$ Procedurally, res judicata fits squarely-though not entirely without controversy - in the category of issues of admissibility, rather than jurisdiction. ${ }^{15}$ While these categories are derived from municipal law and well-understood, ${ }^{16}$ the distinction between the two is worth restating from the point of view of their use in the adjudicative process: an objection to the jurisdiction of the tribunal strikes at the very existence of adjudicative power; an objection to admissibility is 'a plea that the tribunal itself is incompetent to give any ruling at all whether as to the merits or as to the admissibility of the claim. ${ }^{17}$ This qualification has decisive implications in certain contexts, namely investment arbitration, as it is possible to seek

${ }^{12}$ Interpretation of Judgments Nos $7 \& 8$ Concerning the Case of the Factory at Chorzów (Germany v. Poland), PCIJ (Series A) No 11, at 27 (Judge Anzilotti, Dissenting Opinion). One such qualification, however, was not entirely novel: in fact, it was cited to elucidate the meaning of Article 38(1)(c) during the works of the Advisory Committee of Jurists: see PCIJ Procès-Verbaux of the Proceedings of the Committee of Jurists, June 16th-July 24th 1920 (1920), at 335 (Statement of Lord Phillimore). There has been consistent agreement among scholars as to the qualification of res judicata as a general principle of law in the sense of Article 38(1)(c) of the Court's Statute: see H. Lauterpacht, Private Law Sources and Analogies of International Law: With Special Reference to International Arbitration (1927), 206; B Cheng, General Principles of Law: As Applied by International Courts and Tribunals (1953), 337. For more recent assessments see I. Scobbie, 'Res Judicata, Precedent and the International Court: A Preliminary Sketch' (1999) 20 AYBIL 299, at 299; C. Brown, A Common Law of International Adjudication (2007), 155-6; A. Reinisch, 'The Use and Limits of Res Judicata and Lis Pendens as Procedural Tools to Avoid Conflicting Dispute Settlement Outcomes' (2004), 3 LPICT 37, at 44.

${ }^{13}$ Other principles, such as comity, have sometimes been invoked for these purposes: see Southern Pacific Properties (Middle East) Limited v. Arab Republic of Egypt - Decision on Jurisdiction, 27 November 1985, ICSID Case No ARB/84/3. On comity, see T. Schultz and N. Ridi, 'Comity and International Courts and Tribunals' 50 Cornell International Law Journal, 2017.

${ }^{14}$ Ibid at 23.

${ }^{15}$ G. L. Walters, 'Fitting a Square Peg into a Round Hole: Do Res Judicata Challenges in International Arbitration Constitute Jurisdictional or Admissibility Problems?' (2012) 29 Journal of International Arbitration 651; M. Waibel, 'Investment Arbitration: Jurisdiction and Admissibility' University of Cambridge Faculty of Law Research Paper No. 9/2014.

${ }^{16}$ J. C. Wittenberg, 'La recevabilité des réclamations devant les juridictions internationales', 41 RCADI 5, at 8 (1932/III).

${ }^{17}$ G. Fitzmaurice, The Law and Procedure of the International Court of Justice (1986), 438-9; Z. Douglas, The International Law of Investment Claims (2005), 146. 
the review of the tribunal's decision on jurisdiction in municipal courts at the seat of the arbitration or before an $a d$ hoc committee, whereas a decision on admissibility remains final. ${ }^{18}$ The distinction is, instead, less relevant for courts of 'first and last resort' such as the ICJ, where it may, at best, affect the Court's ordering of its own procedure. ${ }^{19}$

The principle of res judicata has been accepted by several international courts and tribunals, either because of its express inclusion in their constitutive instruments, ${ }^{20}$ or by subsequent development through their judicial pronouncements. In spite of its widespread and early recognition, however, to date res judicata has not been applied extensively. ${ }^{21}$ Investment tribunals have been no exception, not unlike the cognate — but less widely accepted — principle of lis alibi pendens, which concerns parallel proceedings rather than successive claims. ${ }^{22}$ It is true, however, that investment disputes present additional complications, ranging from the question of which law should govern the operation of res judicata to the many doubts that can arise with regards to the identity of the parties, matter, and cause of action. ${ }^{23}$ It is difficult to establish, for example, whether and to what extent claims brought by different shareholders, under different BITs, and claiming either the same or different remedies should be considered the same. ${ }^{24}$

More recently, the principle of res judicata has been invoked as a possible remedy to the ill-effects of the proliferation of international courts and tribunals, which, coupled with the relative rigidity of their jurisdictional provisions, results in the possibility of parallel litigation, forum shopping, and divergent decisions on the same cases and issues as well as on the same

\footnotetext{
${ }^{18}$ See J. Paulsson, 'Jurisdiction and Admissibility' in G. Aksen et al. (eds.), Global Reflections on International Law, Commerce and Dispute Resolution: Liber Amicorum in honour of Robert Briner (2005), 601.

${ }^{19}$ Ibid, at 603 .

${ }^{20}$ Such provisions are, however, often broader in scope. For a detailed overview see Y. Shany, The Competing Jurisdictions of International Courts and Tribunals (2003), Chapter 5.

${ }^{21}$ L. B. de Chazournes, 'Plurality in the Fabric of International Courts and Tribunals: The Threads of a Managerial Approach’ (2017) 28 EJIL 13, at 64.

${ }^{22}$ M. Waibel, 'Coordinating Adjudication Processes' in Z. Douglas, J. Pauwelyn and J. E Viñuales (eds.), The Foundations of International Investment Law: Bringing Theory into Practice (2014), 499 at 522; On lis pendens in general see C. McLachlan, Lis Pendens in International Litigation (2009).

${ }^{23}$ H. Wehland, The Coordination of Multiple Proceedings in Investment Treaty Arbitration (2013), 176-7. On res judicata in international commercial arbitration see S. Schaffstein, The Doctrine of Res Judicata Before International Commercial Arbitral Tribunals (2016). A further significant problem is that of the pendence of annulment proceedings in relations to a previous decision: see Perenco Ecuador Limited v. Ecuador, ICSID Case No. ARB/08/6, Decision On Perenco's Application For Dismissal Of Ecuador's Counterclaims, 18 August 2017, para. 49.

${ }^{24}$ J. Magnaye and A. Reinisch, 'Revisiting Res Judicata and Lis Pendens in Investor-State Arbitration', (2016) 15 LPICT 264, at 276.
} 
rules of law, prompting 'fragmentation concerns'. ${ }^{25}$ Since the international legal system does not know general built-in jurisdiction-regulating rules, it has often been submitted that the answer may lie in general principles, of which res judicata is one. ${ }^{26}$ In this context, too, the strictness of the 'triple identity test' may produce undesirable consequences. ${ }^{27}$ Accordingly, attention has been more recently devoted to the rediscovery of the broader construct of issue estoppel, ${ }^{28}$ which may be said to have been sometimes employed by international tribunals, ${ }^{29}$ and the concept of 'judicial comity', which are not subject to the same constraints. ${ }^{30}$

\section{The ICJ and res judicata}

\subsection{The ICJ and the basis of res judicata}

The parties are usually in agreement about its existence and the Court rarely discusses the basis of the principle of res judicata. At this point, however, a distinction must be made between the res judicata effect of the decisions of other international tribunals and that of the Court's own.

\footnotetext{
${ }^{25}$ On the concept of 'fragmentation', see M. Koskenniemi, 'Fragmentation of International Law: Difficulties Arising from the Diversification and Expansion of International Law: Report of the Study Group of the International Law Commission, para. 8, UN Doc. A/CN.4/L.682 (13 April 2006). See also G. Guillaume, 'Advantages and Risks of Proliferation: A Blueprint for Action', (2004) 2 Journal of International Criminal Justice 300, 303; J. Crawford and P. Nevill, 'Relations between International Courts and Tribunals: E "Regime Problem", in M. A. Young (ed.), Regime Interaction in International law: Facing Fragmentation (2012), 211 ; J. Crawford, Chance, Order, Change: The Course of International Law, General Course on Public International Law (2014), 212; P. Webb, International Judicial Integration and Fragmentation (2013).

${ }^{26}$ Shany, supra note 20, Chapter 5; Brown supra note 12, at 29; Crawford and Nevill, supra note 25, at 239; Wehland, supra note 23, at 125-6; C. Giorgetti, 'Horizontal and Vertical Relationships of International Courts and Tribunals - How Do We Address Their Competing Jurisdiction?', (2015) 30 ICSID Review 98.

${ }^{27}$ The CME / Lauder saga is a paradigmatic example: see Ronald S. Lauder v. The Czech Republic, UNCITRAL, Final Award, 3 September 2001; CME Czech Republic B.V. v. The Czech Republic, UNCITRAL, Partial Award, 13 September 2001; CME Czech Republic B.V. v. The Czech Republic, UNCITRAL, Final Award, 14 March 2003. See also Magnaye and Reinisch, supra note 24, at 278.

${ }^{28}$ One example is Apotex Holdings Inc. and Apotex Inc. v. United States of America, ICSID Case No. ARB(AF)/ 12/1, Award, 25 August 2014, paras $7.17 \mathrm{ff}$. See also Magnaye and Reinisch, supra note 24. at 285.

${ }^{29}$ Precedents may be found, for example, in the Orinoco case, where Umpire Plumley said that '[e]very matter and point distinctly in issue in said cause and which was directly passed upon and determined in said decree, and which was its ground and basis, is concluded by said judgment, and the claimants themselves and the claimant government in their behalf are forever estopped from asserting any right or claim based in any part upon any fact actually and directly involved in said decree... The general principle, announced in numerous cases is that a right, question, or fact distinctly put in issue and directly determined, by a court of competent jurisdiction as a ground of recovery, can not be disputed': Claim of Company General of the Orinoco, Report of French-Venezuelan Mixed Claims Commission of 1902, at 355.

${ }^{30}$ Waibel, supra note 23, at 523.
} 


\subsubsection{Decisions of other international courts and tribunals}

Decisions of other international courts and tribunals have been found by the PCIJ and, later, the ICJ to be capable of preclusive effect. ${ }^{31}$ The Court has normally relied on the status of res judicata as a general principle of law to justify its application, though without necessarily offering explanations to that effect. These matters were mostly considered in the exercise of the Court's supervisory functions, though a shift in its approach has ostensibly occurred. For example, in Socobelge, the PCIJ strongly relied on the principle, holding that it meant 'nothing else than recognition of the fact that the terms of that award are definitive and obligatory' and refusing to allow a re-litigation of the case. Yet, in Arbitral Award of the King of Spain and Arbitral Award of 31 July $1989,{ }^{32}$ the Court did not, in fact, refer to the concept, perhaps signalling a drift 'toward something between review and an appeal of the merits'. 33

\subsubsection{Decisions of the ICJ}

The Court's approach to its own decisions retains some important differences. First, the principle is understood to have its basis in the Statute, precisely in Article 59 and 60, which may be understood to govern the formal value of res judicata and its limits. ${ }^{34}$ Article 60 restricts itself to affirming that the decisions of the Court are 'final and without appeal' ${ }^{35}$ It has, however, been read by the Court as 'reflect[ing] the primacy of the principle of res judicata' ${ }^{36}$ This approach has been particularly evident in cases concerning requests for interpretation of judgments of the Court, which are covered by the second sentence of Article 60: as the Court put it in Request for Interpretation of the Judgment of 20 November 1950 in the Asylum Case, the object of any such request 'must be solely to obtain clarification of the meaning and the scope of what the Court has decided with binding force, and not to obtain an answer to

\footnotetext{
${ }^{31}$ Société Commerciale de Belgique (Socobelge) (Belgium v. Greece), PCIJ Series A/B No. 78, at 178.

${ }^{32}$ Arbitral Award of 31 July 1989 (Guinea-Bissau v. Senegal), Judgment of 12 November 1991, [1991] ICJ Rep. 53; Arbitral Award made by the King of Spain on 23 December 1906 (Honduras v. Nicaragua), Judgment of 18 November 1960, [1960] ICJ Reports 192.

${ }^{33}$ W. M. Reisman, 'The Supervisory Jurisdiction of the International Court of Justice: International Arbitration and International Adjudication', in 258 RCADI 9, 34 (1996). See also: Maritime Delimitation and Territorial Questions between Qatar and Bahrain (Qatar v. Bahrain), Merits, Judgment of 16 March 2001, [2001] ICJ Rep. 40, at 76, para. 111.

${ }^{34}$ S. Rosenne, The Law And Practice Of The International Court, 1920-2005 (Martinus Nijhoff Publishers 2005) 1599 .

${ }^{35}$ The judgment becomes final and binding upon the parties on the day of its reading: see Article 94 of the Rules of Court.

${ }^{36}$ Request for Interpretation of the Judgment of 11 June 1998 in the Case concerning the Land and Maritime Boundary between Cameroon and Nigeria (Cameroon v. Nigeria) (Nigeria v. Cameroon), Preliminary Objections, Judgment of 25 March 1999, [1999] ICJ Rep. 31, at 36, para. 12.
} 
questions not so decided. Any other construction of Article 60 of the Statute would nullify the provision of the article that the judgment is final and without appeal' ${ }^{37}$

Article 59, clarifying that such decisions have 'no binding force except between the parties and in respect of that particular case', is actually intended to rule out a doctrine of binding precedent, or at least to exclude the possibility that no states other than those party to the disputes may be bound by the judgment. ${ }^{38}$ The binding nature of the decision on the parties is, however, logically anterior to either conclusion. Further, the term 'decision' is to be interpreted broadly, covering decisions on the merits and preliminary objections alike, ${ }^{39}$ though there are some additional difficulties, mostly relating to the scope, if any, of the preclusive effect of judgments of the latter species. ${ }^{40}$ The formal qualification of the decision does not matter, but compelling reasons suggest that orders on provisional measures should not be given res judicata effect. ${ }^{41}$ It is, however, clear that advisory opinions are not covered by the provision. ${ }^{42}$ Article 61 , too, has bearing on the matter, as it constrains the ability of the parties to seek the revision of a judgment in quite a strict fashion. ${ }^{43}$

\subsection{Effect and scope of res judicata}

The effect of res judicata is hardly controversial: by its operation, 'the matter is finally disposed for good' and further claims are precluded. ${ }^{44}$ However, determining what has been decided with binding force raises more complex questions. On the one hand, the problem is evident in interpreting and revision judgments, which res judicata bars from going beyond the limits of

\footnotetext{
${ }^{37}$ Request for Interpretation of the Judgment of 20 November 1950 in the Asylum Case (Colombia v. Peru), Judgment of 27 November 1950, [1950] ICJ Rep. 395, at 402; Request for Interpretation - Land and Maritime Boundary between Cameroon and Nigeria, supra note 36, at 36-37, para. 12. See also Interpretations of Judgments Nos. 7 und 8 (Factory at Chorzów), Judgment no. 11 1927, PCIJ, Series A No. 13, p. 11.

${ }^{38}$ M. Shahabuddeen, Precedent in the World Court (2007) 99-100; Rosenne, supra note 34, at 1585.

39 Application of the Convention on the Prevention and Punishment of the Crime of Genocide (Bosnia and Herzegovina v. Serbia and Montenegro), Merits, Judgment of 26 February 2007, [2007] ICJ Rep. 43, at 91, para. 117 (hereinafter: Bosnian Genocide-Merits). It must be observed that the Court accepted that observed that a finding that it has jurisdiction does not prevent the subsequent examination of 'any jurisdictional issues later arising that have not been resolved, with the force of res judicata, by such judgment' but only insofar as a decision on them would not contradict the findings made in the earlier judgment (at paras. 127-128).

${ }^{40}$ The question of whet 'they attract the obligation of compliance', which must be answered in the affirmative, is conceptually distinct: see Rosenne, supra note 34, at 804.

${ }^{41}$ Brown, 'Article 59', in A. Zimmermann et al. (eds.), The Statute of the International Court of Justice: A Commentary (2012), 1416.

${ }^{42}$ Rosenne, supra note 32, at 28-9.

${ }^{43}$ Brown, 'Article 59', in A. Zimmermann et al. (eds.), The Statute of the International Court of Justice: A Commentary (2012), 1416.

${ }^{44}$ Barcelona Traction, Light and Power Company, Limited (New Application: 1962) (Belgium v. Spain), Preliminary Objections, Judgment of 24 July 1964, [1964] ICJ Rep. 6, at 20.
} 
the original decision. ${ }^{45}$ On the other hand, and more significantly, the problem must be considered when matters that have already been decided with binding force are brought again under the cloak of an entirely new claim.

As a matter of principle, res judicata only attaches to one portion of the judgment, the dispositif or operative part. ${ }^{46}$ The Court has, on occasion, included in the dispositif of the decision matters that it was not asked to adjudge and were not decisive for the solution given. ${ }^{47}$ The approach has been criticised on the grounds that, by so doing, the Court would exceed its jurisdiction. ${ }^{48}$ The Court's reasoning, which is not included in the dispositif, does nevertheless have relevance: as the PCIJ put it in Polish Postal Service in Danzig, 'all the parts of a judgment concerning the points in dispute... are to be taken into account in order to determine the precise meaning and scope of the operative portion'. ${ }^{49}$ Any preclusive effects of the dispositif are thus to be assessed in light of the motifs. ${ }^{50}$ In the Bosnian Genocide case, the Court introduced a further distinction, between 'first, the issues which have been decided with the force of res judicata, or which are necessarily entailed in the decision of those issues; secondly any peripheral or subsidiary matters, or obiter dicta; and finally matters which have not been ruled upon at all'. 51

This last case is the most interesting - if problematic - comparator for the question of res judicata. As it is well known, the decision arose from the procedural odyssey connected to the Bosnian events, together with the issue of the membership of the FRY to the United Nations and the resulting question concerning its access to the Court. ${ }^{52}$ In this case, too, the parties were in agreement as to the existence of the principle, but disagreed over its scope. The central question was that one party maintained that the issue of party statute had not been conclusively ruled upon in the 1996 Judgment, which had affirmed the Court's jurisdiction. This conclusion appeared to be supported by the wording of the Judgment, as well as by the subsequent Legality

\footnotetext{
${ }^{45}$ Rosenne, supra note 34, at 1612.

${ }^{46}$ Bosnian Genocide-Merits, supra note 39, at 94, para 123.

${ }^{47}$ Oil Platforms (Islamic Republic of Iran v. United States of America), Counter-claims, Judgment of 6 November 2003, [2003] ICJ Rep. 161, at 218, para 125.

${ }^{48}$ Ibid, at 274, para. 10 (Judge Buergenthal, Separate Opinion).

${ }^{49}$ Polish Postal Service in Danzig, Poland v High Commissioner of the League of Nations and Free City of Danzig, Advisory Opinion, PCIJ Series B, No. 11, at 29-30.

${ }^{50}$ Brown, Article 59. It bears noting that the distinction between dispositf and motifs receives implicit endorsement in the wording of Article 95 of the Rules of Court, according to which ' $[t]$ he judgment... shall contain... the reasons in point of law; the operative provisions of the judgment'. On the lack of relevance of this provision for the distinction between ratio and obiter see Rosenne, supra note 34, at 1556.

${ }^{51}$ Bosnian Genocide-Merits, supra note 39, at 95, para 126.

${ }^{52}$ Ibid, at 76 , pars. 80-87.
} 
of Use of Force cases, which had, instead, declined jurisdiction on the basis that the FRY was not a United Nations member and had no access to the Court at the time of its application. ${ }^{53}$ In view of that, Serbia and Montenegro raised again, at the merits phase, the issue of the membership of the FRY to the United Nations and the resulting question concerning its access to the Court. ${ }^{54}$

The Court rejected the contention that res judicata attaches to decisions on preliminary objections and decisions on the merits in different ways. ${ }^{55}$ However, it accepted that '[i]f a matter has not in fact been determined, expressly or by necessary implication, then no force of res judicata attaches to it ${ }^{56}$ It went on to examine the question, distinguishing the issues decided with the force of res judicata from either obiter dicta and 'matters that have not been ruled upon at all', ${ }^{57}$ before finally concluding that 'a determination that all the conditions relating to the capacity of the Parties to appear before it had been met', that is to say, whether the FRY was a party to the Statute had been taken, had been included in its previous judgment. ${ }^{58}$ Accordingly, it applied the principle of res judicata, avoiding a re-opening of the matter. ${ }^{59}$

That a decision on the issue had been taken did not appear, for lack of a more generous word, obvious - indeed, Judges Shi, Ranjeva, and Koroma, the only ones on Bench to have taken part in the 1996 judgment, denied that the Court had definitely ruled on the matter with res judicata effect. ${ }^{60}$ As Wittich notes, reliance on res judicata prevented the Court from having to choose between the equally inconvenient solutions of failing to end the dispute, disrupting the consistency of the case law, and ultimately undermining its own authority. ${ }^{61}$ By way of alternative, one may argue that the fact that such new objections, if successful, would have necessarily reversed the 1996 judgment may suffice as a justification.

\footnotetext{
${ }^{53}$ Legality of Use of Force, at 316-7, paras 96-7.

${ }^{55}$ Ibid, at 95, para. 125.

${ }^{56}$ Ibid., at 96, para. 126.

${ }^{57}$ Ibid.

${ }^{58}$ Ibid. at 99, para. 133.

${ }^{59}$ Ibid. at 101, para. 140.

${ }^{60}$ Ibid., at 267, para 3 (Judges Shi, Ranjeva, and Koroma Dissenting Opinion). S. Wittich, 'Permissible Derogation from Mandatory Rules? The Problem of Party Status in the Genocide Case', (2007) 18 EJIL 591, at 606; See also, generally, C. F. Amerasinghe, 'The Bosnia Genocide Case', (2008) 21 LJIL 411; M. Ottolenghi and P. Prows, 'Res Judicata in the ICJ's Genocide Case: Implications for Other Courts and Tribunals', (2009) 21 Pace International Law Review 37.

${ }^{61}$ Wittich, supra note 55, at 618.
} 


\section{Res judicata in Delimitation of the Continental Shelf}

The above approach was apparently modified in the 2016 judgment on preliminary objections in Delimitation of the Continental Shelf. While the decision raises several interesting problems, for reasons of space and scope this article will restrict itself to the question of res judicata.

\subsection{Overview}

The proceedings under consideration were instituted by Nicaragua in September 2013. The application was thus filed shortly after the decision of the Court's 2012 decision concerning the same parties, which concluded the lengthy case on the Territorial and Maritime Dispute. It will be recalled that Nicaragua had in 2001 instituted proceedings against Colombia on the basis of Article XXXI of the Pact of Bogotà. The dispute concerned territorial sovereignty on certain features and a maritime boundary in the Western Caribbean Sea. After a decision on preliminary objections rendered in 2007, the Court issued a judgment on the merits on 19 November 2012. It found Nicaragua's request to adjudge and declare that "[t]he appropriate form of delimitation, within the geographical and legal framework constituted by the mainland coasts of Nicaragua and Colombia, is a continental shelf boundary dividing by equal parts the overlapping entitlements to a continental shelf of both Parties" admissible. However, it also found that it could not uphold it. Shortly thereafter, relying on the same jurisdictional basis, Nicaragua filed a new application, requesting the Court to adjudge and declare ' $[t]$ he precise course of the maritime boundary between Nicaragua and Colombia in the areas of the continental shelf which appertain to each of them beyond the boundaries determined by the Court in its Judgment of 19 November 2012' and '[t]he principles and rules of international law that determine the rights and duties of the two States in relation to the area of overlapping continental shelf claims and the use of its resources, pending the delimitation of the maritime boundary between them beyond 200 nautical miles from Nicaragua's coast'.

\subsection{Colombia's third preliminary objection}

In its third preliminary objection, Colombia sought to contest the jurisdiction of the Court on the grounds that Nicaragua's requests had been already adjudicated in the 2012 judgment and were thus precluded by the operation of res judicata. ${ }^{62}$ The Court had found that it could not 'uphold the Republic of Nicaragua's claim contained in its final submission I(3)'. ${ }^{63}$ The claim

\footnotetext{
${ }^{62}$ Delimitation of the Continental Shelf, supra note 1, para. 47.

${ }^{63}$ Territorial and Maritime Dispute, supra note 2, at 719, para. 251.
} 
was a request to adjudge and declare that ' $[\mathrm{t}] \mathrm{he}$ appropriate form of delimitation, within the geographical and legal framework constituted by the mainland coasts of Nicaragua and Colombia, is a continental shelf boundary dividing by equal parts the overlapping entitlements to a continental shelf of both Parties'. ${ }^{64}$ Colombia found Nicaragua's first request in the present case to be 'no more than a reincarnation' of the one adjudged in 2012, which, it maintained, the Court admitted but did not uphold on the merits. It similarly found the second request, concerning the identification of the principles and rules of international law determining their rights and obligations in relation to the overlapping continental shelf pending the delimitation of their maritime boundary was dependent on the first.

The parties were in agreement as to the basis and constitutive elements of res judicata. As the Court put it, they disagreed 'on the meaning of the decision adopted by the Court in subparagraph 3 of the operative clause of its 2012 Judgment, and hence on what falls within [its] scope'. ${ }^{65}$

Indeed, Colombia contended that the Court, after 'having found in the operative clause of the 2012 Judgment... that it "cannot uphold" Nicaragua's claim for lack of evidence', was precluded from upholding an identical claim in a later judgment. ${ }^{66}$ Nicaragua, however, relied on Bosnian Genocide to argue that for res judicata to apply 'the matter should have been disposed of by the Court finally and definitively': accordingly, it claimed that the core question was whether the Court had in fact decided the matter of the delimitation of the overlapping continental shelf. ${ }^{67}$

For Colombia, the phrase 'cannot uphold' was to be read in light of paras 126 and 129 of the 2012 judgment, where the Court set out the law applicable to the issue and determined, after observing that 'Nicaragua, in the present proceedings, ha[d] not established that it has a continental margin that extends far enough too overlap with Colombia's 200-nautical-mile entitlement to the continental shelf, measured from Colombia's mainland coast', and that it was 'not in a position to delimit the continental shelf boundary between Nicaragua and Colombia, as requested by Nicaragua, even using the general formulation proposed by it' ${ }^{68}$ Nicaragua, instead, maintained that the 2012 decision had not ruled on the claim on the merits. On the contrary, reading the - admittedly ambiguous - phrase 'cannot uphold' in context

\footnotetext{
${ }^{64}$ Ibid. p. 636, para. 17.

${ }^{65}$ Delimitation of the Continental Shelf, supra note 1, para 54.

${ }^{66}$ Ibid. para 56.

${ }^{67}$ Ibid. para 57.

${ }^{68}$ Ibid. para 66-67; Territorial and Maritime Dispute, supra note 2, at 668-9, paras. 126-129.
} 
revealed that the Court had refused, in light of the fact that Nicaragua had not completed its submission to the Commission on the Limits of the Continental Shelf (CLCS), to rule on the issue and restricted itself to observing that it was not in a position to effect a delimitation. Having in 2013 submitted the necessary information to the CLCS, the Court now possessed the necessary information to effect the delimitation and was not precluded from doing so by the 2012 judgment.

\subsection{The majority Judgment}

The Court chose, in line with its jurisprudence, to qualify the objection as one of admissibility, rather than jurisdiction. ${ }^{69}$ Further, it elected to address the question of the dependence of the second request in its examination of Colombia's fifth objection. ${ }^{70}$ As to res judicata, it accepted the need for the matter to '[have] been determined, expressly or by necessary implication'. Such determination, it continued with its reference to Bosnian Genocide, must be contained in the operative part of the judgment, to be interpreted in context. ${ }^{71}$

Interestingly, the Court noted that 'although in its 2012 Judgment it declared Nicaragua's submission to be admissible, it did so only in response to the objection to admissibility raised by Colombia that this submission was new and changed the subject-matter of the dispute'. ${ }^{72}$ Further, the Court did not accept Nicaragua's claim that the phrase 'cannot uphold' amounted to a rejection of the claim, but neither did it accede to Colombia's view that it necessarily did. Instead, it proceeded to examine the phrase in context to understand whether it amounted to a dismissal for lack of evidence or a refusal to rule on the request because of the failure to fulfil a procedural requirement. ${ }^{73}$ It found that the judgment contained no analysis of the submissions of the parties concerning the evidence provided by Nicaragua. Additionally, the task at hand in the previous case was limited: consequently, the identification of the applicable law did not entail a determination on the substantive legal standards that Nicaragua had to meet to prove its claim. Rather, the Court emphasised Nicaragua's obligation to submit information to the CLCS, which it had failed to do at the time. It also relied on the reference contained in the 2012 judgment to 'present proceedings', which seemed 'to contemplate the possibility of future proceedings' and the fact that the decision is silent as to the maritime areas

\footnotetext{
${ }^{69}$ Interhandel (Switzerland v. United States of America), Preliminary Objections, Judgment of 21 March 1959, [1959] ICJ Rep., 6, at 26.

${ }^{70}$ Delimitation of the Continental Shelf, supra note 1, paras 52-53.

${ }^{71}$ Ibid. para 60-61; Bosnian Genocide-Merits, supra note 39, at 96, para. 126.

${ }^{72}$ Delimitation of the Continental Shelf, supra note 1, para. 72.

${ }^{73}$ Ibid., para. 74.
} 
east of the line lying 200 nautical miles from the islands fringing the Nicaraguan coast. ${ }^{74}$ The Court thus held that its decision not to uphold the claim was only due to Nicaragua's failure to discharge its procedural obligations under the UNCLOS. The procedural requirement having been discharged in 2013, the claim was now ripe.

\subsection{The minority}

Eight judges did not find this interpretation tenable and appended dissenting opinions. In their joint dissent, Judges Yusuf, Cançado Trinidade, Xue, Gaja, Bhandari, Robinson, and Brower (ad hoc) examined four main points. First, after reiterating that res judicata attaches to the dispositif, they stressed the need to examine the meaning of the phrase 'cannot uphold', citing ample case law to the effect that the phrase had been consistently used by the Court to reject claims, rather than refraining or abstaining from making a decision pending the fulfilment of a procedural requirement or the submission of sufficient evidence. ${ }^{75}$ As to the Court's examination of the reasoning underlying the 2012 judgment, they maintained that the lack of a mention of a requirement incumbent on it to submit information to the CLCS demonstrated that the Court had indeed rejected Nicaragua's request for failure to prove the existence of an overlapping extended continental shelf. Further, they contended that 2012 judgment included no suggestion that the Court had intended to admit the possibility of future proceedings, as such indications, in the Court's jurisprudence, had always been explicit. ${ }^{76}$ What is more, and decisively, the Court did not say in paragraph 129 of the 2012 judgment that it was unable to effect a delimitation for lack of a procedural requirement, but it rather said that Nicaragua had not established (in French: 'n'ayant pas... apporté la preuve') that it had any continental margin extending far enough to overlap with Colombia's own. ${ }^{77}$ And, indeed, had it been the case, it would have been redundant for the Court to address the (separate and separately rejected) request of adjudication over Nicaragua's proposed 'general formulation' regarding the outer limits of the extended continental shelf. ${ }^{78}$

\footnotetext{
${ }^{74}$ Ibid., paras. $82-84$

${ }^{75}$ Ibid., paras. 9-18 (Judges Yusuf, Cançado Trinidade, Xue, Gaja, Bhandari, Robinson, and Brower Joint Dissenting Opinion), citing Oil Platforms (Islamic Republic of Iran v. United States of America), Judgment, [2003] ICJ Rep. 172-173, para. 20; Frontier Dispute (Burkina Faso/Niger), Judgment, [2013] ICJ Rep. 2013 66, para. 35; Application for Revision and Interpretation of the Judgment of 24 February 1982 in the Case concerning the Continental Shelf (Tunisia/Libyan Arab Jamahiriya) (Tunisia v. Libyan Arab Jamahiriya), Judgment, 1985 ICJ Rep. 192.

${ }^{76}$ Ibid., at para. 20.

${ }^{77}$ Ibid., at para. 26.

${ }^{78}$ Ibid., at para. 27.
} 
The joint dissent also makes clear that the fact that no analysis of the geological and geomorphological evidence presented by Nicaragua is discussed in the 2012 judgment did not mean that the Court had failed to take it into account. Indeed, the Court 'is not required to, and frequently does not, mention every piece of evidence it considered in reaching a particular conclusion'. ${ }^{79}$ That it did consider it was demonstrated by it finding Nicaragua's information insufficient. ${ }^{80}$ On the contrary, the majority created a procedural requirement (the submission of information to the CLCS) reading it as a condition of admissibility, but incoherently. ${ }^{81}$ In fact, the Court had not, proprio motu, raised an issue of admissibility, allowing Nicaragua's request instead. ${ }^{82}$ It was thus not clear how the Court could not pronounce on the merits of the claim, after declaring it admissible, and how it could later entertain the illogical proposition that a submission of the CLCS had been a procedural requirement all along. ${ }^{83}$

The dissenting judges also observed that, even accepting the majority's interpretation, Nicaragua should not have been allowed an opportunity to remedy the procedural flaw that thwarted its claim. This followed from the principle of ne bis in idem, which, like res judicata, is meant to prevent the ill-effects of repeat litigation. ${ }^{84}$ Further, given that Nicaragua brought an identical claim, under the same basis of jurisdiction, the issue of "exhaustion of treaty processes' could also have precluded the Court to entertaining the request once the case had been 'prosecuted to judgment' ${ }^{85}$

Finally, they concluded by affirming the paramount importance of the objectives pursued by res judicata - finality of litigation and protection from repeat litigation - for the operation of the international legal system and its subjects. Not respecting the principle would have been tantamount to undermining the judicial function and the authority of the Court as the principal judicial organ of the United Nations, especially in the context of a protracted dispute such as that in the case at issue.

Judge Donoghue, too, appended a separate opinion, disagreeing with the majority to a more limited extent. In her view, there could be no doubt that the Court had decided on the

\footnotetext{
${ }^{79}$ Ibid., at para. 30 .

${ }^{80}$ Ibid., para. 31.

${ }^{81}$ Ibid., para. 42.

${ }^{82}$ Ibid., para. 46.

${ }^{83}$ Ibid., para. 48. Judge Robinson observed in his separate dissent that the 'invention' of this requirements by the majority resulted in the application of treaty obligations between a State party and a non-State party of the UNCLOS (paras 15-18). See, however, Separate Opinion of Judge Owada, paras 33-39.

${ }^{84}$ Delimitation of the Continental Shelf, supra note 1, para 59 (Judges Yusuf, Cançado Trinidade, Xue, Gaja, Bhandari, Robinson, and Brower Joint Dissenting Opinion).

${ }^{85}$ Ibid, 61-62.
} 
merits of Nicaragua's first request, by determining that the evidence submitted was no proof that Nicaragua's continental shelf entitlement overlapped with Colombia's mainland entitlement. ${ }^{86}$ However, no determination had been made regarding the question of whether one such overlap existed between Nicaragua's entitlement and that of Colombia's, generated by its islands, lying beyond 200 miles from its coasts. Accordingly, no preclusive effect could be said to follow on the matter. ${ }^{87}$

\section{Appraisal and implications}

\subsection{The principle of res judicata and what it covers}

If there is a lesson to be learned from the Delimitation saga is that agreement on the law is, in and by itself, a modest accomplishment: the same rules, though properly understood, can bring to paradoxically divergent solutions-hardly a novel conclusion in the theory of international law. ${ }^{88}$ In the case at issue the disagreement did not concern the preclusive effect to be attributed the decision, but the scope of the decision itself, which remained equivocal. The ambiguity in the 2012 decision, however, does not appear to have been of the 'Delphic' kind, designed to avoid 'the indignity of an impugned judgment' ${ }^{89}$ Rather, as Judge Donoghue remarked in her dissent, it is ascribable to the Court's usual 'laconic' drafting style, where little discussion is generally offered of party positions before an equally brief conclusion is asserted. ${ }^{90}$ The remark is particularly compelling as the same judge had, in the 2012 decision, appended a separate opinion lamenting the insufficient discussion in the judgment of the inadequacy of Nicaragua's evidence. ${ }^{91}$

In fact, the judgment of the Court makes clear that there is broad agreement as to both the applicability of the principle of res judicata in international dispute settlement and its requirements, confirming the principle affirmed in Bosnian Genocide: "[i]f a matter has not in fact been determined, expressly or by necessary implication, then no force of res judicata attaches to it; and a general finding may have to be read in context in order to ascertain whether a particular matter is or is not contained in it". ${ }^{92}$

\footnotetext{
${ }^{86}$ Delimitation of the Continental Shelf, supra note 1, paras. $20 \mathrm{ff}$. (Judge Donoghue Dissenting Opinion).

${ }^{87}$ Ibid. para. 45.

${ }^{88}$ See generally M. Koskenniemi, From Apology to Utopia: The Structure of International Legal Argument (2006).

${ }^{89}$ WM Reisman, 'The Enforcement of International Judgments' (1969) 63 AJIL 1, at 4.

${ }^{90}$ Delimitation of the Continental Shelf, supra note 1, at 8, para. 36 (Judge Donoghue Dissenting Opinion).

${ }^{91}$ Territorial and Maritime Dispute, supra note 2, at 756, para 17 (Judge Donoghue Dissenting Opinion).

${ }^{92}$ Bosnian Genocide-Merits, supra note 39, para 126.
} 
To a reader of both Nicaragua $v$ Colombia decisions, that the Court chose to stress its reliance on the Bosnian Genocide judgment may seem ironic. In the 2007 case, as Wittich puts it, the Court's conclusion on the applicability of res judicata had only been possible because of a 'magical cut', that is to say, the argument that the 1996 judgment included-necessarily, if implicitly - a finding on the (preliminary) issue of whether FRY was a party to the Statute, that is, something that neither the parties or the Court raised or discussed. The Delimitation of the Continental Shelf Judgment runs in the opposite direction: Colombia's third preliminary objection was rejected on the basis that the first Judgment contained no indications that the Court had ruled (on the merits) on Nicaragua's request. On this point, one does not see how the two judgments can be reconciled - indeed the Court found itself evenly split, and it bears noting that the disagreement extended, almost to the same degree, to the judges who had taken part to the 2012 decision, six of whom voted in favour, four against. ${ }^{93}$

The approach the Court had taken in Bosnian Genocide meant that its reading of res judicata — admittedly not flawless, broad and based on an implied finding — served the purpose of allowing it to put an end to protracted litigation. In Delimitation of the Continental Shelf, the Court did just the opposite by denying that it had pronounced on Nicaragua's request on the merits. The indications that the Court had in fact ruled on the matter were admittedly scarce. Yet, it can be argued that the situation was not much clearer in Bosnian Genocide. Even more problematic is the fact that the Court justified the result to which it arrived with the introduction of what amounts to a 'procedural requirement', which, had it been there, should have rendered Nicaragua's claim inadmissible in the first case - and which, somehow, did not. It is true that in 2012 the Court noted that 'in deciding on the admissibility of the new claim, the Court is not addressing the issue of the validity of the legal grounds on which it is based'. ${ }^{94}$ However, nothing would have prevented it from raising the objection proprio motu, which-again - it did not do. ${ }^{95}$

\subsection{Finality, coherence, and the limits of the judicial process}

The majority's approach to the issue of res judicata can be read as a rejection of an excessive rigidity of the judicial process when justice so requires — in other words, a refutation of the idea

\footnotetext{
93 In favour: Abraham, Owada, Yusuf, Greenwood, Bennouna, Tomka, Sebutinde, Skotnikov (ad hoc for Nicaragua in the latter case); Against: Yusuf, Cançado Trinidade, Xue, Donoghue.

${ }^{94}$ Territorial and Maritime Dispute, supra note 2, at 665, para. 112.

${ }^{95}$ See Joint Dissenting Opinion para 46.
} 
that finality should entail infallibility. ${ }^{96}$ This is because of the broad substantive consequences of res judicata, which mean that the decision binds the parties in or outside the courtroom.

In the case at issue, had res judicata intervened on Nicaragua's failure to prove that it had a shelf entitlement, the problem would have been twofold: on the one hand, the 2012 Judgment would have conclusively governed the relations between Nicaragua and Colombia. This would have been problematic in light of Nicaragua's aspiration to contest the illegality of the Colombian conduct on its alleged entitlement-incidentally, the subject of Alleged Violations of Sovereign Rights and Maritime Spaces in the Caribbean Sea. ${ }^{97}$ On the other hand, the 2012 Judgment would not have been opposable to third states, with Nicaragua free to establish, by going through the CLCS process, 'the outer limits of the continental margin visà-vis all parties to UNCLOS.${ }^{98}$ In other words, a finding of res judicata would have run counter the traditional considerations relating to the establishment of a border, where there is hardly any need to stress that certainty and finality are important values - though at times the point was emphasised. ${ }^{99}$ As it is frequently affirmed, a judgment concerning the territory or borders of a state may well be binding, qua judgment, only on the parties, but are, in practice, 'effective erga omnes for all other states'. ${ }^{100}$ The argument can thus be made that concerns of consistency and coherence may have justified the approach adopted in the Delimitation case.

It is understandable that such complex circumstances may warrant a different approach. At the same time, however, one wonders if the bounds of the judicial process have not been overstepped. As Robert Jennings once argued, 'it is possible exaggerate the importance of the

\footnotetext{
${ }^{96}$ See Brown v. Allen, 344 U.S. 443 (1953), at 540 (Jackson, J. concurring): 'We are not final because we are infallible, but we are infallible only because we are final'.

${ }^{97}$ Alleged Violations of Sovereign Rights and Maritime Spaces in the Caribbean Sea (Nicaragua v. Colombia), Preliminary Objections, Judgment of 17 March 2017 (not yet published).

${ }^{98}$ Separate Opinion of Judge Greenwood, para 6.

99 Temple of Preah Vihear (Cambodia v. Thailand), Judgment, [1962] ICJ Rep. 6, at 34.

${ }^{100}$ Rosenne, supra note34, at 209; C. de Visscher, 'La chose jugée devant la cour internationale de la haye' (1965) 1 Revue Belge de Droit International 5, at 9. See also Brown, 'Article 59', supra note 43. The expression 'erga omnes' has also been employed in this context to refer to the precedential force of the pronouncements of international adjudicators: Condorelli, 'L'autorité des décisions des juridictions internationales permanents', in 'La jurisdiction internationale permanente, Colloque SFDI de Lyon 1987 (1987), 277. Note that the view that a judgment on a territorial question should have erga omnes effect has been disputed by Scobbie relying on the authority of Continental Shelf (Libyan Arab Jamahiriya/Malta) (Italian Intervention), [1984] ICJ Rep. 3, at 2627. In that occasion, however, the Court approached the problem from the perspective of an adjudicator having to deal with prior decisions on the same issue and that of a state that could have potentially intervened, but did not. Suffice it to observe that the expression is used here in its broader scope, envisaged by De Visscher and acknowledged by Scobbie, that the opposability of the judgment to other states descends from its capability to establish an objective state of affairs. That no decision of international tribunals may "cast international law in stone' is readily acknowledged: see S. Talmon, 'The South China Sea Arbitration and the Finality of "Final" Awards' (2017) 8 JIDS 388, at 391.
} 
judicial function in international law' ${ }^{101}$ Though this axiomatic proposition is a provocation, it bears recalling in this context to remind ourselves that, while adjudication may preclude the use of alternative means of dispute settlement, this is not necessarily so after the judgment. ${ }^{102}$ Such means were, in this case, open to the parties as far as the delimitation of an overlapping entitlement beyond 200nm from Nicaragua's coast was concerned. Ideed, Judge Donoghue noted in her opinion that a finding of res judicata would have concerned the determination of a failure to prove an entitlement, but could be no proof of the opposite fact. ${ }^{103}$ Accordingly, the possibility of taking advantage of other means of dispute settlement to resolve the issue would have been open to the parties. Granted, such alternative means may, in a given case, be less convenient for the parties than judicial settlement. However, when available, they remain an option of which cognisance must be taken when an applicant has already had its day in Court.

It may also be observed that the odds of resolving a dispute through negotiation after a judgment too might be, in a way, dependent on the application res judicata. It has been noted, with the broader question of compliance in mind, that ICJ decisions - and, to an extent, ICJ proceedings too-can serve as 'impetus for negotiated settlement'. ${ }^{104}$ In this context, their ability to do so depends on their finality as much as it does on their bindingness. In other words, the possibility of reopening a case beyond the limits set by Articles 60 and 61 is detrimental to the ability of the judgment to prompt the settlement of the dispute in one way or the other.

\subsection{The value of finality and the protection of the judicial function}

As the Court put it in Bosnian Genocide, its function, 'according to Article 38 of its Statute, is to "decide", that is, to bring to an end, "such disputes as are submitted to it". ${ }^{105}$ What does this observation mean? It is submitted that the answer dispute does not require a learned digression

\footnotetext{
${ }^{101}$ R. Y. Jennings, 'Recent Developments in the International Law Commission: Its Relation to the Sources of International Law' (1964) 13 ICLQ 385, at 394.

${ }^{102}$ For an overview of the relationship between negotiation and judicial settlement see K. Wellens, Negotiations in the Case Law of the International Court of Justice: A Functional Analysis (2016). See also J. G. Merrills, International Dispute Settlement (2011), 158. Moreover, the Court has always been mindful of the fact that 'The judicial settlement of international disputes "is simply an alternative to the direct and friendly settlement of such disputes between the parties"': see North Sea Continental Shelf (Federal Republic of Germany/Denmark), Judgment, [1969] ICJ Rep. 48, para. 87, citing with approval Free Zones of Upper Savoy and the District of Gex (France v Switzerland), Order, PCIJ Series A No 22.

${ }^{103}$ Delimitation of the Continental Shelf, supra note 1, para. 45 (Judge Donoghue Dissenting Opinion) (emphasis added). Judge Greenwood appears to disagree with this proposition in his dissent (para 6).

${ }^{104}$ AP Llamzon, 'Jurisdiction and Compliance in Recent Decisions of the International Court of Justice' (2007) 18 EJIL 815 , at 848.

${ }^{105}$ Delimitation of the Continental Shelf, supra note 1, para. 66 (Judges Yusuf, Cançado Trinidade, Xue, Gaja, Bhandari, Robinson, and Brower Joint Dissenting Opinion)..
} 
on the opposition between historical and legal truth, or on whether international litigation should be considered informed by an adversarial and transactional paradigm or otherwise. ${ }^{106}$ Rather, the answer may be found in the Statute, with its closed list of options for reopening a case, and the Court's consistent approach to the value of the finality of judgments. ${ }^{107}$ In this context, it bears noting that the Court does not know a form of appeal: as it has been observed, 'the right of appeal per se represents the recognition that finality may be compromised by infallibility which may require correction'. ${ }^{108}$ Such a compromise is only tolerable insofar as it structurally maintains the unity of the judicial process and does not, accordingly, undermine the authority of the adjudicator. ${ }^{109}$ The revision process can only be partially subsumed under this framework, as it expressly absolves the Court from any flaw that may plague its judgment. ${ }^{110}$

The statutory basis of the principle and its sound rationale should thus also inform its application in terms of scope. The pursuit of the end of litigation is inherent to the judicial function, not unlike — and, to a degree, for the same reasons of - the principle of non liquet. ${ }^{11}$ In this regard, the views of the dissenting judges are to be preferred: reading res judicata too narrowly undermines the judicial function, 'undercut[ting] the certainty, stability, and finality that judgments of th[e] Court should provide'. ${ }^{112}$

This is not to say that the practical application of the principle is devoid of complications. In this regard, one point raised in the decision and supported by the partly dissenting Judge Donoghue (the Joint Dissent does not address the issue) serves as a paradigmatic example: in the 2012 judgment the Court had said nothing about 'the maritime areas located to the east of the line lying 200 nautical miles from the islands fringing the

\footnotetext{
${ }^{106}$ M. R. Damaska, The Faces of Justice and State Authority: A Comparative Approach to the Legal Process (1991), 145. See also Delimitation of the Continental Shelf, supra note 1, para. 30 (Judge Owada Separate Opinion).

${ }^{107}$ Land and Maritime Boundary case (Request for Interpretation), supra, fn. 1, ICJ Rep. (1999), pp. 31, 36 (para. 12).

${ }^{108}$ N Gal-Or, 'The Concept of Appeal in International Dispute Settlement' (2008) 19 European Journal of International Law 43, 51.

${ }^{109}$ E Harnon, 'Res Judicata and Identity of Actions Law and Rationale' (1966) 1 Israel Law Review 539, 539; Cited in Gal-Or (n 100) 51.

${ }^{110}$ Article 61 provides that an application for revision of a judgment may only be based upon the discovery of a decisive fact, unknown to the Court and to the party claiming revision at the time of the judgment, and on condition that its ignorance was not due to the party's negligence.

${ }^{111}$ P. Weil, 'The Court Cannot Conclude Definitively ... Non Liquet Revisited Chapter 1: Questions of Theory' (1998) 36 Columbia Journal of Transnational Law 109, 114.

${ }^{112}$ Delimitation of the Continental Shelf, supra note 1, para. 67 (Judges Yusuf, Cançado Trinidade, Xue, Gaja, Bhandari, Robinson, and Brower Joint Dissenting Opinion).
} 
Nicaraguan coast, beyond which the Court did not continue its delimitation exercise, and to the west of the line lying 200 nautical miles from Colombia's mainland'. ${ }^{113}$ The Court however says that it 'was, as regards these areas, faced with competing claims by the Parties concerning the continental shelf'. Indeed, Nicaragua had requested that the islands of San Andrés and Providencia and Santa Catalina 'be enclaved and accorded a maritime entitlement of 12 nautical miles'. ${ }^{114}$ That the Court did not rule on the matter of delimitation of the continental shelf in the area is apparent, but Nicaragua did not request such ruling either. Should the Court have considered this claim as barred?

The answer largely depends on one's understanding of the scope of res judicata, which in turn, hinges upon the accepted rationale for the principle. It is respectfully submitted that, in a potentially never-ending dispute such as this one, a broad doctrine of claim estoppel (precluding claims that, had reasonable diligence been exercised, might have been brought at the time) should be taken in serious consideration. One such doctrine would also discourage tactical claim splitting and foster efficiency in international adjudication. Yet, even adopting one such model — which, in any event, has not yet received any express acceptance- this approach would not be devoid of difficulties. ${ }^{115}$ In that regard, the dissenting judges' espousal of the doctrine of 'exhaustion of treaty processes' does not necessarily come across as an easier solution, as it is subject to the same pitfalls: determining whether a 'particular matters of complaint' has truly been prosecuted to judgment. ${ }^{116}$

\section{Conclusion}

'The Court of Justice', Salmond observed, 'may make mistakes but no one will be heard to say so. For their function is to terminate disputes and their decisions must be accepted as final beyond question'. ${ }^{117}$ With this in mind, the application of the res judicata principle by the ICJ in the Delimitation of the Continental Shelf judgment may appear concerning. The choice to

\footnotetext{
${ }^{113}$ Delimitation of the Continental Shelf, supra note 1, para 83.

${ }^{114}$ Territorial and Maritime Dispute, supra note 2, at 671, para. 134.

${ }^{115}$ Wittich observes, for example, that issue estoppel could be a possible reading of Bosnian Genocide-Merits, supra note 39. However, even extending the doctrine to determinations taken by the Court motu proprio, its breadth would still be, in all likeliness, excessive: see supra note 55, at 607. Nor did cases like Apotex (supra note 28) produce such a broad preclusive effect.

${ }^{116}$ Delimitation of the Continental Shelf, supra note 1, paras. 59-62 (Judges Yusuf, Cançado Trinidade, Xue, Gaja, Bhandari, Robinson, and Brower Joint Dissenting Opinion). The expression was employed in Barcelona Traction, Preliminary Objections, [1964] ICJ Rep. 6, at 20, at 26.

${ }^{117}$ John Salmond, Jurisprudence (1947), 484. It is telling that in Bosnian Genocide-Merits, supra note 39, the Court recited the brocard res judicata pro veritate habetur in its entirety. See also Gal-Or, supra note 10051.
} 
construe res judicata narrowly may be seen as a precedent with regards to an Applicant's ability to reopen a case beyond the bounds of what the Statute permits. As the dissenting Judges noted, this undermines the authority of the Court, and the judicial function writ large.

Accordingly, it is submitted that the application of res judicata should be informed by the purposes of the principle: finality of litigation and protection from repeat litigation. The Court did not do so in Delimitation, thus allowing the continuance of a long-running difference, seemingly emerging as an enabler of litigious states without a solid justification. Moreover, the Court's narrow reading of the principle emerges as an implicit endorsement of a party's claimsplitting strategies. From the perspective of the sound administration of justice, such a position is inefficient for both the Court (which could see an increased case load) and a respondent state (which may be exposed to vexatious claims and face higher transaction costs).

A cavalier attitude to the issue of finality may also have other, wide-ranging implications. Beyond the capacity of its jurisprudence to influence the approach of other tribunals, the point could be made that the Court's must consider certain profiles of 'institutional responsibility'-for example, as an organ that is routinely granted supervisory functions in relation with arbitral proceedings and awards. ${ }^{118}$ The Court's traditional judiciousness in resolving these disputes has been recognised, ${ }^{119}$ but, if it does not stand by the finality of its own judgments, it may appear inadequately placed for this and other tasks.

\footnotetext{
${ }^{118}$ W. M. Reisman, 'The Supervisory Jurisdiction of the International Court of Justice: International Arbitration and International Adjudication', in 258 RCADI 9 (1996), at 221. The point has been raised that this role is assigned to the ICJ by default in the ICSID Convention (Article 64): see C. N. Brower, M. Ottolenghi and P. Prows, 'The Saga of CMS: Res Judicata, Precedent and the Legitimacy of ICSID Arbitration' in C. Binder et al. (eds.), International Investment Law for the 21st Century (2009), 848.

119 ibid.
} 